\title{
Mandenkan
}

MANDENIKAN Bulletin semestriel d'études linguistiques mandé

$50 \mid 2013$

Numéro 50

\section{Polysemy patterns of two postpositions marking class-membership and property assignment in Jeli (Central Mande)}

La polysémie de deux postpositions marquant l'appartenance à une classe et attribution d'une caractéristique en jeli (Mandé Central)

ПОЛИСЕМИЯ МОДЕЛЕЙ ДВУХ ПОСЛЕЛОГОВ, ОБОЗНАЧАЮЩИХ ПРИНАДЛЕЖНОСТЬ К КЛАССУ И ПРИПИСЫВАЮЩИХ СВОЙСТВА В ДЖЕЛИ (ЦЕНТРАЛЬНЫЕ МАНДЕ)

\section{Holger Tröbs}

\section{(2) OpenEdition}

\section{Journals}

Electronic version

URL: https://journals.openedition.org/mandenkan/275

DOI: 10.4000/mandenkan.275

ISSN: 2104-371X

\section{Publisher}

Llacan UMR 8135 CNRS/Inalco

\section{Printed version}

Date of publication: 1 December 2013

Number of pages: 131-146

ISSN: 0752-5443

\section{Electronic reference}

Holger Tröbs, "Polysemy patterns of two postpositions marking class-membership and property assignment in Jeli (Central Mande)", Mandenkan [Online], 50 | 2013, Online since 01 December 2013, connection on 08 July 2021. URL: http://journals.openedition.org/mandenkan/275 ; DOI: https:// doi.org/10.4000/mandenkan.275

This text was automatically generated on 8 July 2021.

Les contenus de Mandenkan sont mis à disposition selon les termes de la Licence Creative Commons Attribution - Pas d'Utilisation Commerciale - Partage dans les Mêmes Conditions 4.0 International. 


\section{Polysemy patterns of two postpositions marking class- membership and property assignment in Jeli (Central Mande)}

La polysémie de deux postpositions marquant l'appartenance à une classe et attribution d'une caractéristique en jeli (Mandé Central)

ПОЛИСЕМИЯ МОДЕЛЕЙ ДВУХ ПОСЛЕЛОГОВ, ОБОЗНАЧАЮЩИХ ПРИНАДЛЕЖНОСТЬ К КЛАССУ И ПРИПИСЫВАЮЩИХ СВОЙСТВА В ДЖЕЛИ (ЦЕНТРАЛЬНЫЕ МАНДЕ)

Holger Tröbs

\section{AUTHOR'S NOTE}

The present article is based on a paper read at the $3^{\text {rd }}$ International Conference on Mande Languages and Linguistics, Paris, September 14-17, 2011. The paper was presented during the workshop on "Identification and related functions" organised by Denis Creissels.

\section{Abbreviations}

COND $=$ conditional

$\mathrm{CONJ}=$ conjunction

$\mathrm{COP}=$ copula

$\mathrm{CR}=$ current relevance

$\mathrm{DEF}=$ definite marker

DEM $=$ demonstrative

FOC $=$ focus particle

IPFV = imperfective

INT = interrogative

$\mathrm{NEG}=$ negation 
Part.Res $=$ resultative participle

$\mathrm{PFV}=$ perfective

$\mathrm{PL}=$ plural

POSS $=$ possessive marker

$\mathrm{Pp}=$ postposition

$\mathrm{REL}=$ relative marker

$\mathrm{SG}=$ singular

TOP = topic marker

\section{Introduction}

1 Jeli or Jeri is an endangered Central Mande language still spoken by less than 2000 speakers in the north of the Ivory Coast, that is, in Korhogo and surrounding areas (for a detailed list of villages with estimated number of Jeli speakers, cf. Kastenholz 2001). Jeli belongs to the Manding-Jogo branch within the Central Mande languages (cf. Kastenholz 1996: 70f.). Its nearest relative is Jogo ("Ligbi") spoken in Ghana (BrongAhafo Region) and some settlements in neighbouring areas of Ivory Coast (Bondoukou, Bouna).

2 In contrast to other Central Mande languages such as Jogo, Koranko, Bambara, Vai and Yalunka, the concepts of class-membership ('Musa is a hunter') and property assignment ('Musa is president') on the one hand and equation ('Musa is the winner', 'Musa is my father') on the other are formally differentiated in Jeli. Whereas classmembership and property assignment are expressed by a copula and a postpositional phrase containing a predicate nominal and a postposition (i.e., kón or ré), the predicate nominal in nominal sentences expressing equational function is linked to the subject only by a copula, but is not further marked by a postposition.

The purpose of this paper is threefold.

1. Data on identificational clauses (with special reference to class-membership and property assignment) in Jeli are presented and discussed within the framework of the functionaltypological approach (Sections 2 and 3 ).

2. The polysemy pattern of the two postpositions involved in marking class-membership and property assignment are investigated in terms of metaphorical extensions and iconic motivation (Section 4).

3. By exploring the range of meanings associated with postpositions used to express classmembership in Jeli the empirical base for a typology of "identificational" postpositions in the Mande languages should be broaden.

\section{Theoretical preliminaries}

\subsection{Semantic subtypes of identificational sentences}

According to a widely accepted typology of constructions featuring "predicate nominals" (cf. Dik 1989: 161-182, Hengeveld 1992, Payne 1997: 111-119, Stassen 1997), we may distinguish between two major subtypes of identificational sentences.

In the first type "a certain property such as group membership (class-inclusion) or a positive or negative quality is predicated of a referential subject in the form of a non- 
referential predicate noun" (Sasse 2007: 28). This semantic subtype (for example: 'Madu is a hunter', 'Madu is communist') is called "property assignment", "class-inclusion", "proper inclusion", "class-membership" or "ascriptive type" in the literature (cf. Dik 1989: 180, Payne 2007: 114, Hengeveld 1992: 110f.).

The second type, named "equative type", asserts "that a particular entity (the subject of the clause) is identical to the entity specified in the predicate nominal" (Payne 1997: 114). This type can by exemplified by sentences such as 'Madu is my father' or 'Madu is the winner'. ${ }^{1}$

It must, however, be kept in mind that in many languages the equative type (having definite predicate nominals) can oscillate between a specificational and an ascriptive (characterizational) reading. As has been shown by Sasse (2007: 29), this is especially the case when the predicate nominal is a possessive phrase such as 'my father' in 'Ali is my father'. In this example, the specificational reading is indicated if "Ali is the one that has to be identified with", whereas the same sentence has an ascriptive reading, if it is understood as "Ali has the property of being in a paternal relationship of me" (Sasse 2007: 29).

\subsection{Conceptual transfer and encoding strategies of identificational sentences}

7 In his typological study "Intransitive predication" Stassen (1997) discusses different sets of encoding mechanisms for intransitive predicates, i.e., event, class-membership, location and property concepts in the languages of the world (his sample contains 410 languages). Moreover, Stassen proposes a set of formal and semantic principles in order to account for the variation of intransitive predicates across languages.

As regards the encoding of class-membership predicates, Stassen (1997: 111-113) argues that the use of the equational strategy seems the 'natural' option for the encoding of class-membership predicates. This argumentation is motivated by the semantic concept of "iconicity" ("which states, wherever possible, form will mirror function", Stassen 1997: 113). Thus, the close semantic relation (sometimes resulting in ambiguity) between class-membership predications and equational sentences can be held responsible for the unique encoding of class-membership and equation in many languages of the world.

9 However, opposed to this general concept of "iconicity", language structure may also be shaped by a general principle of "structural economy", called by Stassen (1997: 112) "The Economy Principle of Predicate Encoding: Languages tend to minimise the number of different surface patterns in the encoding of their intransitive sentences". This formal principle accounts for a uniform pattern for locational, class-membership and event clauses.

For at least some languages, the 'desire' to create a uniform surface pattern for all intransitive sentences may be stronger than the 'desire' to maintain semantic transparency. (Stassen 1997: 112)

Moreover, on the basis of the localistic interpretation of the concept of predication, the unique structural features of the encoding of class-membership and event predicates across languages can be explained by tracing them back to features of the locational strategy. Thus, according to the framework of localism, predication, i.e. the association of a particular, individual entity with semantic classes of predicates such as class- 
membership, events and properties can be conceived "as location of an entity into a space which is defined by the predicate" (Stassen 1997: 15).

[...] there exists a tradition of a LOCALISTIC interpretation of the concept of predication, in which events, properties, and classes are seen as 'places' at which (the referent of) the subject comes to be situated. [...] Thus, we can distinguish between predicates which situate an entity in a CONCRETE spatial location and predicates which assign an ABSTRACT, non-physical and non-spatial, location to their subjects. (Stassen 1997: 15)

\section{Identificational sentences in Jeli²}

11 As stated before, the concepts of class-membership and equation are formally differentiated in Jeli. Class-membership predicates are expressed by a copula and a postpositional phrase containing a non-referential ${ }^{3}$ predicate nominal and a locative postposition. Two locative postpositions are used in the marking of class-membership predicates, i.e., the inessive Pp kón and the adessive Pp ré. These two postpositions are used interchangeably, as shown in examples (1) and (2). ${ }^{4}$

\begin{tabular}{|l|l|l|l|l|l|}
\hline & \multicolumn{5}{l|}{ CLASS-MEMBERSHIP / PROPERTY ASSIGNMENT } \\
\hline & \multicolumn{5}{|l|}{ NS + à + NS + kóy / ré; predicate nominal is non-referential } \\
\hline$(1)$ & $\grave{o}$ & tà=na & gbìra & sí & $k$ kóy / ré \\
\hline & 2PL & FOC=PL.COP & stupid.person & FOC & Pp \\
\hline & \multicolumn{5}{l}{} \\
\hline
\end{tabular}

\begin{tabular}{|l|l|l|l|l|}
\hline (2) & nàa & jèli & sí & kón / ré \\
\hline & 1SG.COP & Jeli & FOC & Pp \\
\hline \multicolumn{3}{|l}{ 'I am a Jeli.' } \\
\hline
\end{tabular}

Since class-membership predicates in Jeli are always marked by a locative postposition, they are metaphorically interpreted as having a spatial dimension, i.e., as an interior when used with the Pp kón or as a place when used with the Pp ré. Class-membership sentences in Jeli thus locate someone in or at a class or group ('I am in / at the group of Jeli'). In Anderson's terms (1971: 207), class-membership predicate nominals are "a subtype of locative".

13 The concept of equation, however, is expressed in Jeli by a copula and a bare nominal. The predicate nominal is not further marked by a postposition, as shown in examples (3) and (4). Thus, no localistic interpretation can be suggested.

\begin{tabular}{|l|l|}
\hline & EQUATION \\
\hline & NS + à +NS; predicate nominal is referential \\
\hline
\end{tabular}




\begin{tabular}{|l|l|l|l|l|}
\hline (3) & kpùru-kara-mugo=ni & sá & $\grave{a}$ & tà=ni \\
\hline & leather-sew-man.DEF=PL & FOC.COP & $1 \mathrm{PL}$ & FOC=PL \\
\hline & 'We are the leatherworkers.' \\
\hline
\end{tabular}

\begin{tabular}{|l|l|l|l|l|l|l|}
\hline$(4)$ & $\grave{1}$ & tà & mó & sá & ná & wù-mó \\
\hline & $3 \mathrm{SG}$ & FyyOC & chef.DEF & FOC.COP & 3PL.POSS & head-chef.DEF \\
\hline \multicolumn{7}{|l}{} \\
\multicolumn{7}{|l}{ 'This person is their leader.' } \\
\hline
\end{tabular}

14 To summarize, on the basis of the localistic interpretation of the concept of predication, the structural features of the encoding of class-membership predicates in Jeli can be explained by tracing them back to features of the locational strategy. The same can be assumed for intransitive event predicates by taking their possible diachronic developments into account, cf. (5a)-(5c).

\begin{tabular}{|c|c|c|c|c|}
\hline & \multicolumn{4}{|c|}{ Location Schema ( $\mathrm{X}$ is at $\mathrm{Y}$ ) } \\
\hline$(5 a)$ & $n i ́$ & $k p o ́=a ̀$ & gbàn-dó & $r \varepsilon$ \\
\hline & 3PL & all=COP & house-door.DEF & $\mathrm{Pp}$ \\
\hline & \multicolumn{4}{|c|}{ 'All of them are at the entry door.' } \\
\hline
\end{tabular}

\begin{tabular}{|l|l|l|l|l|}
\hline & \multicolumn{4}{|c|}{ Reconstructed Progressive } \\
\hline$(5 \mathrm{~b})$ & $*_{n i}$ & $k p o ́=\grave{a}$ & $k \grave{=}=0$ & $r \varepsilon ́$ \\
\hline & $3 \mathrm{PL}$ & all=COP & talk=DEF & $\mathrm{Pp}$ \\
\hline & \multicolumn{4}{|c|}{ 'All of them are at talking.' } \\
\hline
\end{tabular}

\begin{tabular}{|c|c|c|c|}
\hline & \multicolumn{3}{|c|}{ Progressive / Habitual } \\
\hline \multirow[t]{3}{*}{ (5c) } & $n i ́$ & $k p o ́=a ̀$ & $k \grave{u}-\varepsilon$ \\
\hline & 3PL & all=COP & talk-IPFV \\
\hline & \multicolumn{3}{|c|}{ 'All of them are talking / talk. } \\
\hline
\end{tabular}

15 The Jeli language has opted for a uniform surface pattern for locational, classmembership and (historically) intransitive event sentences by way of locational takeover. The locational strategy prevails over the equational strategy as regards the encoding of class-membership predicates. Or, to put it in Stassen's terms (1997: 112), for the Jeli language, the 'desire' to create a uniform surface pattern for all intransitive 
sentences was stronger than the 'desire' to mirror the close semantic relation between equational predicates and class-membership predicates formally by taking over the equational strategy.

\section{Polysemy pattern of the two postpositions involved in marking class-membership}

16 As noted above, two spatial postpositions are involved in marking class-membership predicates. As the spatial postpositions in Central Mande in general (cf. Tröbs 1998, 1999), these two postpositions express mainly topological relations (proximity, contact, containment) but are neutral with respect to the differentiation of Source and Goal. It should thus be kept in mind that directional meaning components are only lexicalized in verbs (so called directional or orientation verbs), but not in postpositions. Following Lüpke (2007: 553-561), while describing semantic extensions of the two spatial postpositions we will specify which semantic path relation, namely Source or Goal (although indicated by the directional semantics of the verb), is marked by them.

\subsection{Polysemy pattern of the spatial Pp kón}

17 Kón is a lexical postposition with the meaning 'inside, in'. It goes back to the relational noun meaning 'stomach'. The distinction between relational noun and lexical postposition is not always easy to draw. When used as a lexical Pp, kóy neither accepts nominal determiners such as the definite marker -o nor modifiers. ${ }^{5}$

\begin{tabular}{|l|l|l|l|l|}
\hline (6) & nà & kóy=à & nà & díbe-n $\varepsilon$ \\
\hline & $1 S G$ & stomach=IPFV & 1 SG & hurt-IPFV \\
\hline \multicolumn{3}{|l}{ 'My stomach hurts (me).' } \\
\hline
\end{tabular}

18 In its original spatial meaning the Pp kón indicates a specific topological or Ground relation, i.e., insideness or containment, as shown in example (7).

\begin{tabular}{|c|c|c|c|c|c|}
\hline & \multicolumn{5}{|c|}{ PRIMARILY INESSIVE SEMANTICS WITH CONCRETE NOUNS } \\
\hline (7) & $i$ & $m i ̀$ & $d \grave{a}(d \grave{o}+\grave{a})$ & $y i^{\prime}=0$ & kón... \\
\hline & $3 S G$ & REL & TOP.COP & water $=\mathrm{DEF}$ & Pp \\
\hline & \multicolumn{5}{|c|}{ 'what is in (inside) the water...' } \\
\hline
\end{tabular}

The extensions of kón include the encoding of inessive semantics with abstract nouns as shown in (8) and (9), location in a place with non-motion verbs (10), movement towards a Goal with allative verbs (11) and movement away from a Source with ablative verbs (12). 


\begin{tabular}{|l|l|l|l|l|l|l|}
\hline & \multicolumn{5}{|l|}{ INESSIVE SEMANTICS WITH ABSTRACT NOUNS } \\
\hline$(8)$ & $n a ́$ & $m i ̀$ & $k \grave{l} l \varepsilon$ & tìga & jèli-kpuras & kón? \\
\hline & 3PL.IPFV & what & call.IPFV & peanut & Jeli-language.DEF & Pp \\
\hline & \multicolumn{7}{|l}{} \\
\hline
\end{tabular}

\begin{tabular}{|l|l|l|l|l|}
\hline$(9)$ & yé & jí & jòli & kón \\
\hline & 2SG.COP & year & how.many & Pp \\
\hline & \multicolumn{4}{|l}{ 'How old are you?' (lit. In how many years are you?) } \\
\hline
\end{tabular}

\begin{tabular}{|l|l|l|l|l|l|l|l|}
\hline \multicolumn{7}{|c|}{ LOCATION IN A PLACE WITH NON-MOTION VERBS } \\
\hline$(10)$ & $n \grave{a}$ & $\varnothing$ & wà & $k p o ̀ o$ & $k a ̀-\varnothing$ & bògo & $k$ ón \\
\hline & $1 \mathrm{SG}$ & $\mathrm{PFV}^{6}$ & $\mathrm{CR}^{7}$ & hoe.DEF & leave-PFV & bush.DEF & Pp \\
\hline \multicolumn{7}{|l}{} \\
\hline
\end{tabular}

\begin{tabular}{|l|l|l|l|l|l|}
\hline \multicolumn{5}{|c|}{ movement towards a goal with allative verbs } \\
\hline$(11)$ & $\grave{1}$ & $\varnothing$ & s̀̀- $\varnothing$ & bògo & $k$ kón \\
\hline & $3 S G$ & PFV & enter-PFV & bush.DEF & Pp \\
\hline \multicolumn{6}{|l}{} \\
\hline
\end{tabular}

\begin{tabular}{|l|l|l|l|l|l|l|}
\hline \multicolumn{6}{|c|}{ movement away from a source with ablative verbs } \\
\hline$(12)$ & $\grave{i}$ & $\varnothing$ & wà & búJ- $\varnothing$ & b̀̀go & kón \\
\hline & 3SG & PFV & CR & come.from-PFV & bush.DEF & Pp \\
\hline \multicolumn{6}{|l}{} \\
\hline
\end{tabular}

Furthermore, the Pp kón is employed to mark abstract predicative possession by using the Location Schema ( $\mathrm{Y}$ is located in $\mathrm{X}$ ) encoding the possessor $(\mathrm{X})$ as a locative complement and the possessee as the subject (cf. Heine 1997: 91f.). As shown in examples (13) and (14), the possessee is physical or psychological state.

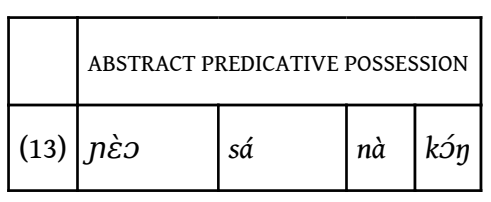




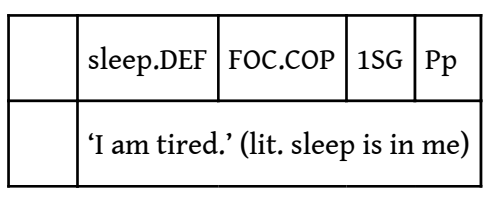

\begin{tabular}{|l|l|l|l|l|}
\hline$(14)$ & $n \grave{a}$ & fàli=à & $\grave{i}$ & $k o ́ n$ \\
\hline & $1 \mathrm{SG}$ & antidote=COP & $3 \mathrm{SG}$ & $\mathrm{Pp}$ \\
\hline & [Some girls said:] 'He (the youngest brother) is mine.' (lit. My antidote is in him) \\
\hline
\end{tabular}

In the uses studied so far, the Pp kón functions as a Ground-denoting Pp in the expression of locative and possessive relations as well as motion events.

Moreover, the Pp kón is also used to mark predicative arguments of verbs expressing quality and transformation, as shown in (15) and (16).

\begin{tabular}{|l|l|l|l|l|l|l|l|}
\hline & \multicolumn{6}{|l|}{ PREDICATIVE ARGUMENTS OF VERBS EXPRESSING QUALITY (ESSIVE FUNCTION) } \\
\hline$(15)$ & $n a ́$ & $\grave{a}$ & tà=ni & file-nc & jògo-ni & sí & kón \\
\hline & 3PL.IPFV & $1 \mathrm{PL}$ & FOC=PL & see-IPFV & Dyula & FOC & Pp \\
\hline & \multicolumn{7}{|c|}{ 'They (people from Katala) consider us (the Jeli from Korhogo) to be Dyula.' } \\
\hline
\end{tabular}

\begin{tabular}{|l|l|l|l|l|l|}
\hline & \multicolumn{5}{|l|}{ PREDICATIVE ARGUMENTS OF VERBS EXPRESSING TRANSFORMATION (TRANSLATIVE FUNCTION) } \\
\hline$(16)$ & $n d a ̀=n i$ & $\varnothing$ & má- $\varnothing$ & mùgu=ni & kón \\
\hline & 3PL.FOC=PL & PFV & make-PFV & person=PL & Pp \\
\hline & \multicolumn{7}{l}{} \\
\hline
\end{tabular}

As noted by Creissels (2008: 1), in contrast to canonical arguments of verbs, predicative arguments "do not denote an entity involved in the verbal event, but a property predicated of the referent of another argument of the same verb". Typical predicative arguments appear in constructions with verbs such as 'to become', 'to transform', 'to act as', 'to consider to be', 'to pretend to be', etc. Thus, we observe a semantic affinity (i.e., property assignment) between predicative arguments and predicate nominals in identificational clauses.

Verbs whose argument structure includes a predicative argument lend themselves to a semantic decomposition including a predication of identification. (Creissels 2008: 1)

The identical encoding of class-membership predicate nominals and predicative arguments of quality and transformation verbs is thus an example of iconic motivation: similar form reflects similar meaning or conceptual structure (cf. Croft 1990: \$7.3).

Finally, our corpus contains one example in which kón marks the experiencer of the emotion verb kúdia 'be pleasant'. Here, the Pp ré can be used alternatively to kón. 


\begin{tabular}{|c|c|c|c|c|c|c|c|}
\hline \multirow[b]{2}{*}{ (17) } & \multicolumn{7}{|c|}{ EXPERIENCER OF AN EMOTION VERB } \\
\hline & sún & mì & dò & kúdia & kذ̀ndi & $m \dot{\varepsilon}$ & kóy / ré \\
\hline & thing & REL & TOP & be.pleasant & bird & DEM & $\mathrm{Pp}$ \\
\hline & \multicolumn{7}{|c|}{ '....which food this bird likes.' (lit. which food is pleasant for the bird) } \\
\hline
\end{tabular}

Let us now turn to the other Pp involved in marking class-membership.

\subsection{Polysemy pattern of the Pp ré}

$R \varepsilon$ is a formal Pp with spatial ('at') and associative meaning ('with'). The assumed original meaning of $r \varepsilon$ is adessive, i.e., it indicates proximity by stating that 'the Figure is close to a spatial Ground', as shown in (18).

\begin{tabular}{|l|l|l|l|l|}
\hline \multicolumn{4}{|l|}{ ADESSIVE MEANING } \\
\hline$(18)$ & $n i ́$ & sàga-ra & gbày-dó & ré \\
\hline & 3 PL & sit-Part.Res & house-door.DEF & Pp \\
\hline & \multicolumn{3}{|l}{ 'They are sitting at the entry door.' } \\
\hline
\end{tabular}

The metaphorical extensions of the adessive semantics of $r \varepsilon$ include the expression of temporal meaning (19), the marking of abstract predicative possession where the possessee (Y), i.e., a psychological state (20), a physical state (21) or another abstract concept (22), is located at the possessor (X), and the encoding of comparison (23). According to Heine (1997: 117), comparison is expressed by using a variant of the Location Schema, namely, ' $\mathrm{X}$ is $\mathrm{Y}$ at $\mathrm{Z}$ ', which establishes a spatial relation between the comparee (X) and the standard ( $\mathrm{Z}$ ). The Location Schema can, thus, be paraphrased as " $\mathrm{X}$ has property $\mathrm{Y}$, and if $\mathrm{Z}$ is placed in the same location as $\mathrm{X}, \mathrm{X}$ has more than $\mathrm{Z}$ does" (Heine 1997: 114).

\begin{tabular}{|c|c|c|c|c|c|c|c|}
\hline \multirow[b]{2}{*}{ (19) } & \multicolumn{7}{|c|}{ TEMPORAL MEANING (LOCATION IN TIME) } \\
\hline & $y \grave{~}$ & $\sin \varepsilon$ & $y \grave{~}$ & tàna- $\varnothing$ & télo & mì & $r \varepsilon ́$ \\
\hline & 3SG.IPFV & look.for.IPFV & 3SG.IPFV & get.red-PFV & time.DEF & REL & $\mathrm{Pp}$ \\
\hline & 'When ( & $\mathrm{m}$ & he 1 & fruit) is & ng red & & \\
\hline
\end{tabular}

\begin{tabular}{|l|l|l|l|}
\hline & \multicolumn{3}{|l|}{ ABSTRACT PREDICATIVE POSSESSION (Y IS LOCATED AT X) } \\
\hline$(20)$ & yákili=à & $\grave{ }$ & $r \varepsilon ́$ \\
\hline
\end{tabular}




\begin{tabular}{|l|l|l|l|}
\hline & intelligence=COP $3 S G$ & $\mathrm{Pp}$ \\
\hline & 'He is intelligent.' (lit. Intelligence is at him) \\
\hline
\end{tabular}

\begin{tabular}{|l|l|l|l|l|}
\hline$(21)$ & $k$ ùgu=à & $\grave{a}$ & $k p o ́$ & $r \varepsilon ́$ \\
\hline & hunger=COP & $1 \mathrm{PL}$ & all & $\mathrm{Pp}$ \\
\hline & \multicolumn{4}{|l}{} \\
\hline
\end{tabular}

\begin{tabular}{|c|c|c|c|c|c|c|}
\hline$(22)$ & $n \grave{a}$ & rá & $c \grave{a}=\grave{a}$ & $i$ & tà & $r \varepsilon ́$ \\
\hline & $1 S G$ & POSS & credit $=\mathrm{COP}$ & $2 S G$ & FOC & $\mathrm{Pp}$ \\
\hline & \multicolumn{6}{|c|}{ 'You owe me money.' (lit. My credit is at you) } \\
\hline
\end{tabular}

\begin{tabular}{|c|c|c|c|c|c|c|c|}
\hline \multirow[b]{2}{*}{$(23)$} & \multicolumn{7}{|c|}{ COMPARISON BY USING THE LOCATION SCHEMA (X IS Y AT Z) } \\
\hline & $i$ & $k a ́$ & gbj̀ & $i$ & bála-ná & wòm $\varepsilon$ & $r \varepsilon ́$ \\
\hline & $3 S G$ & POSS & tree.DEF & $3 S G$ & become.big-Part.Res & DEM & $\mathrm{Pp}$ \\
\hline & 'Hi & e i & gger & & & & \\
\hline
\end{tabular}

In addition to the uses mentioned so far, $r \varepsilon ́$ is employed to encode associative meaning (comprising comitative and instrumental). As argued by Croft (1991: 197), the comitative function is related to the adessive function "by the COMITATIVEPROXIMITY metaphor, in which a spatial expression of co-location such as 'near' or 'among' develops into a comitative form". A similar argumentation is found in Anderson (1971: 4), who argues that the comitative function has an underlying locative structure since it indicates typically "the person along with whom". Moreover, the conflation of comitative and instrumental meanings into one marker is widely attested in the languages of the world (Croft 1991, Heine et al. 1991). The polysemy between comitative and instrumental markers is motivated by the COMPANION-INSTRUMENT metaphor that states that ACCOMPANIMENT also indicates INSTRUMENTALITY (cf. Lakoff/Johnson 1980: 134f.). The comitative function is exemplified in (24)-(27). ${ }^{8}$ Examples (28) and (29) illustrate the instrumental function.

\begin{tabular}{|c|c|c|c|c|c|}
\hline \multirow[b]{2}{*}{$(24)$} & \multicolumn{5}{|c|}{ COMITATIVE FUNCTION } \\
\hline & Mori $=\grave{a}$ & jì- $\varepsilon$ & $\grave{a}$ & $r \varepsilon ́$ & súma \\
\hline & Mori=IPFV & spend.the.night-IPFV & $1 \mathrm{PL}$ & Pp & tomorrow \\
\hline & \multicolumn{5}{|c|}{ 'Mori will spend the night at our place/with us [chez nous] tomorrow.' } \\
\hline
\end{tabular}




\begin{tabular}{|l|l|l|l|l|}
\hline$(25)$ & sá & $n i ́$ & $y i ́=0$ & ré! \\
\hline & come & and & water=DEF & $\mathrm{Pp}$ \\
\hline & \multicolumn{4}{|l|}{ 'Bring water!' (lit. come with water) } \\
\hline
\end{tabular}

\begin{tabular}{|l|l|l|l|l|l|l|l|l|l|}
\hline (26) & fi & sí & $\varnothing$ & wà & tà'a- $\varnothing$ & wá & ní & í & ré? \\
\hline & today & FOC & PFV & CR & go.away-PFV & INT & and & 2SG & Pp \\
\hline \multicolumn{10}{|c|}{ 'Have you gone mad today?' [lit. today has gone away with you?] } \\
\hline
\end{tabular}

\begin{tabular}{|c|c|c|c|c|c|}
\hline \multirow[t]{2}{*}{ (27) } & $y \grave{e}$ & $k \grave{u}-\varepsilon$ & ní & Soma & $r \varepsilon ́$ \\
\hline & 3SG.IPFV & talk-IPFV & and & Soma & $\mathrm{Pp}$ \\
\hline & ' $\mathrm{He}$ is $\mathrm{sp}$ & 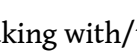 & (t) & th/tc & \\
\hline
\end{tabular}

\begin{tabular}{|l|l|l|l|l|l|l|l|l|}
\hline \multicolumn{7}{|l|}{ INSTRUMENTAL FUnCtion } \\
\hline$(28)$ & $n a ̀ ~$ & $\varnothing$ & $n a ̀ ~$ & wù=o & yìri- $\varnothing$ & (ní) & jèse=o & ré \\
\hline & $1 \mathrm{SG}$ & $\mathrm{PFV}$ & $1 \mathrm{SG}$ & head=DEF & bind-PFV & (and) & yarn=DEF & $\mathrm{Pp}$ \\
\hline \multicolumn{7}{|l}{} \\
\hline
\end{tabular}

\begin{tabular}{|l|l|l|l|l|l|l|}
\hline$(29)$ & wáli=o=à & dègay & kánkJy & ní & kálay & $n \varepsilon ́$ \\
\hline & boy=DEF=COP & grave & Pp & and & bow & Pp \\
\hline & 'The boy is on the grave with a bow.' \\
\hline
\end{tabular}

Moreover, causation can be perceived as place with the Pp ré. In example (30), the postpositional phrase kùgo ré is viewed as cause "triggering" the verbal action (cf. Radden 1985: 182).

\begin{tabular}{|c|c|c|c|c|c|c|c|}
\hline \multirow[b]{2}{*}{ (30) } & \multicolumn{7}{|c|}{ “TRIGGERING CAUSE" } \\
\hline & $d i=0=n i$ & dà & $d \grave{i}-\varepsilon$ & nà & nò & kùgo & $r \varepsilon ́$ \\
\hline & child $=\mathrm{DEF}=\mathrm{PL}$ & TOP.IPFV & cry-IPFV & $1 S G$ & $\mathrm{Pp}$ & hunger.DEF & $\mathrm{Pp}$ \\
\hline & \multicolumn{7}{|c|}{ 'The children are crying for me (because) of hunger.' } \\
\hline
\end{tabular}

31 According to its broad semantics, i.e., spatial, comitative, instrumental and cause, $r \varepsilon ́$ is used to mark participants of certain intransitive verbs as well as the third participant 
of three-place verbs. ${ }^{9}$ Depending on the directional semantics of the intransitive verb

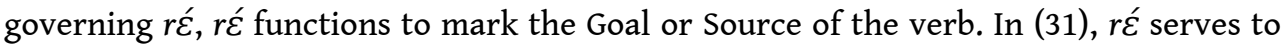
encode the Goal, in (32) it marks the Source.

\begin{tabular}{|l|l|l|l|l|l|l|}
\hline \multicolumn{6}{|c|}{ GOAL WITH INTRANSITIVE DIRECTIONAL VERBS } \\
\hline$(31)$ & $\grave{ }$ & $\emptyset$ & wà & màga- $\varnothing$ & sìbe=o & ré \\
\hline & 3SG & PFV & CR & touch-PFV & meat=DEF & Pp \\
\hline & \multicolumn{6}{l}{} \\
\hline
\end{tabular}

\begin{tabular}{|l|l|l|l|l|l|l|}
\hline \multicolumn{7}{|l|}{ SOURCE WITH INTRANSITIVE DIRECTIONAL VERBS } \\
\hline$(32)$ & $\grave{i}$ & $\emptyset$ & wà & dàga- & $\grave{a}$ & ré \\
\hline & 3SG & PFV & CR & slip.away-PFV & $1 \mathrm{PL}$ & Pp \\
\hline & 'It (the Jeli language) has slipped away (from us).' [it has become disused] \\
\hline
\end{tabular}

The above mentioned concept of "triggering cause" (Radden 1985: 182) can be held responsible for the use of $r \varepsilon$ with emotion verbs such as 'to dream about', as shown in example (33).

\begin{tabular}{|c|c|c|c|c|c|c|c|}
\hline \multirow[b]{2}{*}{ (33) } & \multicolumn{7}{|c|}{ “TRIGGERING CAUSE” WITH INTRANSITIVE REACTIONAL OR EMOTION VERBS } \\
\hline & ní & $i$ & sá & kúro & má-Ø & $y{ }^{\prime}=0$ & $r \varepsilon ́ . .$. \\
\hline & CONJ & $2 \mathrm{SG}$ & COND & dream.DEF & do-PFV & water $=\mathrm{DEF}$ & $\mathrm{Pp}$ \\
\hline & 'If & & $b c$ & ater...' & & & \\
\hline
\end{tabular}

Furthermore, $r \varepsilon ́$ is used to mark the third participant of transfer verbs. In (34) ré serves to encode the animate Goal or Receiver of a verb of change of possession, in (35) ré is used to indicate the 'information asked for' in a verb of transfer of information.

\begin{tabular}{|c|c|c|c|c|c|c|c|c|}
\hline \multirow[b]{2}{*}{ (34) } & \multicolumn{8}{|c|}{ THIRD PARTICIPANT OF TRANSFER VERBS (VERBS OF CHANGE OF POSSESSION) } \\
\hline & $n \grave{a}$ & $\varnothing$ & wà & wáro & $l \grave{e}-\varnothing$ & nà & séy & $r \varepsilon ́$ \\
\hline & $1 \mathrm{SG}$ & PFV & CR & money.DEF & give-PFV & $1 S G$ & father & $\mathrm{Pp}$ \\
\hline & 'I ha & & & nresent] & Pev & atl & & \\
\hline
\end{tabular}

third participant of transfer verbs (verbs of change of information) 


\begin{tabular}{|l|l|l|l|l|l|l|l|l|}
\hline$(35)$ & má & $\varnothing$ & wà & i & tà & nigi- $\varnothing$ & kili=o & ré? \\
\hline & who & PFV & CR & $2 S G$ & FOC & ask-PFV & way=DEF & Pp \\
\hline \multicolumn{1}{|c|}{ 'Who has asked you for the way?' } \\
\hline
\end{tabular}

As noted by several authors (cf. Croft 1990: 166, Lüpke 2007: 557; 561), there is a clear metaphorical relationship between the change in location and the transfer of possession of an object. In this metaphorical extension, changes of possession are treated like changes in location. In a further extension, transfers of information are conceived as transfers of possession of an object. To put it in Lüpke's (2007: 557) terms, what events of change of location, events of change of possession, and events of change of information have in common is that all three types "entail at least a metaphorical transfer of an entity from a Source to a Goal, applying a metaphor I will henceforth label "transfer-metaphor". A still more abstract extension of the "transfer metaphor" can be held responsible for the use of $r \varepsilon$ to mark the animate Goal or malefactive with the generic verb má 'to do', as shown in (36).

\begin{tabular}{|c|c|c|c|c|c|c|c|}
\hline \multirow[b]{2}{*}{ (36) } & \multicolumn{7}{|c|}{ THIRD PARTICIPANT OF TRANSFER VERBS (ABSTRACT EXTENSION OF THE “TRANSFER METAPHOR”) } \\
\hline & $y \grave{~}$ & $\sin \varepsilon$ & $y \grave{~}$ & mì & $m a ́-\varnothing$ & $n \grave{a}$ & $r \varepsilon ́ ?$ \\
\hline & 3SG.IPFV & look.for.IPFV & 3SG.IPFV & what & do-PFV & $1 \mathrm{SG}$ & $\mathrm{Pp}$ \\
\hline & 'What & the lion) & ari & e $\mathrm{h}$ & & & \\
\hline
\end{tabular}

Finally, according to its associative meaning, $r \varepsilon ́$ can also be used to mark the transferred object in a change of possession verb. In this so called "Theme-Instrument Strategy" (Lüpke 2005: 217) the object of transfer is treated as an Instrument and the Goal or target of transfer is associated with the Theme. Thus, in example (37), ré is employed to indicate the gift or the good of transfer by treating it as an instrument.

\begin{tabular}{|l|l|l|l|l|l|l|l|}
\hline & \multicolumn{6}{|l|}{ TRANSFERRED OBJECT IN A CHANGE OF POSSESSION VERB } \\
\hline$(37)$ & $\grave{a}$ & $\varnothing$ & $\grave{ }$ & $k$ kú- $\varnothing$ & wári & ré & té \\
\hline & $1 \mathrm{PL}$ & PFV & 3 SG & present-PFV & money & Pp & NEG \\
\hline \multicolumn{7}{|l}{} \\
\hline
\end{tabular}

\section{Summary}

Our findings on the different polysemy pattern of the Pp kón and ré as well as the related explanatory parameters are summarized in Table 1. 
Table 1: Main extensions of the spatial postpositions kón and ré

\begin{tabular}{|c|c|c|}
\hline $\mathrm{Pp}$ & Function & $\begin{array}{l}\text { Motivational basis for extensions based on } \\
\text { cross-linguistically attested conceptual } \\
\text { transfer patterns }\end{array}$ \\
\hline kóy & $\begin{array}{l}\text { Locative relations; i.e., denotes specific Ground } \\
\text { relations (insideness) in the expression of } \\
\text { location, possession, motion events (with } \\
\text { directional verbs: Source/Goal) }\end{array}$ & $\begin{array}{l}\text { Abstract predicative possession is expressed } \\
\text { with the Location Schema ( } \mathrm{Y} \text { is located in } \mathrm{X}) \\
\text { (Heine 1997: 91f.) }\end{array}$ \\
\hline & Class-membership & $\begin{array}{l}\text { Class-membership predicate nominals are } \\
\text { "a subtype of locative" (Anderson 1971: 207) }\end{array}$ \\
\hline & $\begin{array}{l}\text { Predicative arguments of verbs expressing } \\
\text { quality and transformation (essive/translative) }\end{array}$ & $\begin{array}{l}\text { Semantic affinity between class- } \\
\text { membership predicate nominals and } \\
\text { predicative arguments (= iconic motivation, } \\
\text { cf. Creissels 2008) }\end{array}$ \\
\hline ré & $\begin{array}{l}\text { Locative relations; i.e., denotes specific Ground } \\
\text { relations (proximity) in the expression of } \\
\text { location and possession as well as in events of } \\
\text { change of location (with directional verbs: } \\
\text { Source and Goal) }\end{array}$ & $\begin{array}{l}\text { Abstract predicative possession is expressed } \\
\text { with the Location Schema ( } \mathrm{Y} \text { is located at X) } \\
\text { (Heine 1997: 91f.) }\end{array}$ \\
\hline & Class-membership & $\begin{array}{l}\text { Class-membership predicate nominals are } \\
\text { "a subtype of locative" (Anderson 1971: } \\
\text { 207); "The Economy Principle of Predicate } \\
\text { Encoding" (Stassen 1997: 112) }\end{array}$ \\
\hline & Comparison & $\begin{array}{l}\text { Comparison is expressed with the Location } \\
\text { Schema (X is Y at Z) (Heine 1997: 117) }\end{array}$ \\
\hline & Comitative, Instrument & $\begin{array}{l}\text { COMITATIVE-PROXIMITY metaphor (Croft } \\
\text { 1991: 197); COMPANION-INSTRUMENT } \\
\text { metaphor (Lakoff \& Johnson 1980: 134) }\end{array}$ \\
\hline & “Triggering cause" & $\begin{array}{l}\text { Causation viewed as a place "triggering" the } \\
\text { verbal action (Radden 1985: 182) }\end{array}$ \\
\hline & Third participant with transfer verbs & $\begin{array}{l}\text { Changes of possession and information are } \\
\text { treated like changes of location (Croft 1990: } \\
\text { 166; Lüpke 2007) }\end{array}$ \\
\hline
\end{tabular}

The treatment of the polysemy pattern of the two postpositions used to encode classmembership predicates in Jeli was based on the localist hypothesis, according to which spatial concepts are more basic than other concepts and therefore serve as source pattern for the conceptualization of non-spatial concepts (Anderson 1971, Lakoff \& Johnson 1980, Lyons 1977).

Since these two "identificational" postpositions clearly have a spatial component (insideness, proximity), we have argued that their "identificational meaning" is derived 
from their spatial meaning and treated class-membership predicate nominals as "a subtype of locative" (Anderson 1971: 207).Moreover, by using several common conceptual metaphors we have shown that the basic concepts "space" and "change-inspace" served as templates for the development of a set of other postpositional functions such as the encoding of abstract predicative possession, comparison, comitative, instrumental, "triggering cause", and third participants with transfer verbs.

In contrast to the lexical Pp kón which still preserves its concrete spatial (inessive) meaning, the formal Pp ré has a highly general semantics and is used besides its adessive semantics to cover all kinds of situations entailing metaphorical transfer.

Finally, neither of the two postpositions can be used to mark beneficiaries (for, to somebody's benefit) or oblique agents.

\section{BIBLIOGRAPHY}

ANDERSON J., 1971, The grammar of case: towards a Localistic theory, Cambridge, Cambridge University Press.

BLECKE Th., 1994, “Vollverb, Kopula, Postposition: Das Morphem yé im Bambara”, in Th. GEIDER, \& R. KASTENHOLZ (eds.). Sprachen und Sprachzeugnisse in Afrika. Eine Sammlung philologischer Beiträge Wilhelm J.G. Möhlig zum 60. Geburtstag zugeeignet, Köln, Köppe, pp. 49-62.

BYBEE J. et al., 1994, The evolution of grammar, Chicago, The University of Chicago Press.

CREISSELS D., 2008, "Predicative argument marking: the case of transformation verbs. Cognitive and functional perspectives on dynamic tendencies in languages”, Tartu, May 29 - June 01, 2008.

CROFT W., 1990, Typology and universals, Cambridge, Cambridge University Press.

CROFT W., 1991, Syntactic categories and grammatical relations, Chicago, Chicago University Press. DIK S., 1989, The theory of functional grammar. Part I: The structure of clause, Dordrecht, Foris.

HAIMAN J., 1980, “The iconicity of grammar”, Language 56, pp. 515-540.

HAIMAN J. (ed.), 1985, Iconicity in syntax, Amsterdam, Benjamins.

HEINE B., 1997, Cognitive foundations of grammar, New York/Oxford, Oxford University Press.

HEINE B., CLAUDI U., HÜNNEMEYER F., 1991, Grammaticalization: a conceptual framework, Chicago, The University of Chicago Press.

HENGEVELD K., 1992, Non-verbal predication. Theory, typology, diachrony, Berlin/New York, de Gruyter.

KASTENHOLZ R., 1996, Sprachgeschichte im West-Mande: Methoden und Rekonstruktionen. Mande Languages and Linguistics, Vol. 2., Köln, Köppe.

KASTENHOLZ R., 2001, « Le jèri.kúò (langue mandé des Jèri) : répartition géographique et matériel lexical », Mandenkan 37, pp. 49-88. 
KLAMER M., 1994, Kambera: a language of Eastern Indonesia, Den Haag, Holland Academic Graphics.

LAKOFF G., JOHNSON M., 1980, Metaphors we live by, Chicago, University of Chicago Press.

LYONS J., 1977, Semantics, 2 vols (continuously paginated), Cambridge, Cambridge University Press.

LÜPKE F., 2005, A grammar of Jalonke argument structure (MPI series in psycholinguistics), PhD dissertation, University of Nijmegen.

LÜPKE F., 2007, “On giving, receiving, affecting and benefitting in Jalonke”, Linguistics 45 (3), pp. 539-576.

PAYNE Th., 1997, Describing morphosyntax: a guide for field linguists, Cambridge, Cambridge University Press.

RADDEN G., 1985, "Spatial metaphors underlying prepositions of causality”, in W. PAPROTTÉ \& R. DIRVEN (eds.), The ubiquity of metaphor, Amsterdam/Philadelphia, Benjamins, pp. 177-207.

SASSE H.-J., 2007, "Nominal" and "adjectival" predication in Lowland Eastern Cushitic, in J. CRASS \& R. MEYER (eds.), Deictics, copula and focus in the Ethiopian convergence area, Köln, Köppe, pp. 27-52.

STASSEN L., 1997, Intransitive predication, Oxford, Clarendon.

TRÖBS, H., 1998, Funktionale Sprachbeschreibung des Jeli (West-Mande), Mande Languages and Linguistics, Vol. 3, Köln, Köppe.

TRÖBS H., 1999, “Lokalisation im Maninka (West-Mande)”, Sprachtypologie und Universalienforschung 3/4, pp. 365-379.

\section{NOTES}

1. The terminology for constructions involving predicate nominals is thus quite varied and highly confusing. We use "identificational sentences" as a cover term comprising two major subgroups: "class-membership" (rather than "class-inclusion" or "proper inclusion") and "equation" (rather than "identificational clause").

2. For a description of one-argument identificational (presentational) clauses (NS + sùn), cf. Tröbs (1998: 175ff.).

3. Referentiality (involving discourse referentiality and definiteness, cf. Tröbs 1998: 106-111, Payne 1997: 263-266) is indicated by the definite marker -o. It either "leans on" the preceding noun or replaces the final vowel of the preceding noun if the noun constitutes the only element of the nominal phrase.

4. The definite marker $-o$ and the plural marker $-n i$ are considered to be enclitics. In contrast to suffixes, they do not exhibit a high degree of selection with respect to their stems but, syntactically, attach to the borders of a nominal phrase.

The copula / imperfective auxiliary -à is also treated as an enclitic, since its host is not a specific kind of stem but a specific phrasal node, i.e., the subject NP (cf. Klamer 1994: 50 for pronominal cliticisation in Kambera). Moreover, the copula / imperfective auxiliary -à cannot stand on its own in a normal utterance. Finally, the copula / imperfective auxiliary -à often merges with the preceding element.

5. It should be noted that nouns ending in a velar nasal such as kón 'stomach' do not differ in the surface between definite (cf. kón < kóy +o) and indefinite (cf. kóy) forms.

6. The distinction between perfective and imperfective aspect is basic to the Jeli TAM system. This opposition is marked by the combination of auxiliaries and inflectional verb stems. Thus, the imperfective aspect is encoded by the auxiliary (predicate marker) - $a$ in combination with 
the imperfective verb form which is derived principally through suffixation (cf. Tröbs 1998: 84-89). In contrast to the imperfective aspect, the perfective aspect is unmarked twofold. First, it has no overt perfective auxiliary. Second, the perfective verb form is unmarked. In order to keep an explicit marking for these two non-overt elements, an overt " $\varnothing$ " is included in the Jeli line, and "PFV" in the gloss line.

7. Current relevance $(\mathrm{CR})$ indicates a specific deictic component of meaning, i.e., an action which took place in the past is relevant to the moment of speech. According to Bybee et al. (1994: 86), the specification of current relevance is lost, when an anterior (or perfect) changes into the past or perfective.

8. Note that comitative semantics is usually expressed by the coordinating conjunction $n i$ [N1 ní N2] which assigns equal rank to the elements it connects (cf. Mori ní Soma wà cí 'Mori and Soma have arrived').

9. For a thorough semantic analysis of postpositions marking the third participant of three-place verbs in Yalunka, cf. Lüpke (2007: Section 3).

\section{ABSTRACTS}

This paper examines the polysemy patterns of two postpositions marking class-membership and property assignment in Jeli, a Central Mande language, in terms of metaphorical extensions and iconic motivation. It thus aims at broadening the empirical base for a typology of "identificational" postpositions in the Mande languages.

Cet article traite des modèles de la polysémie de deux postpositions marquant l'appartenance à une classe et l'attribution d'une caractéristique en jeli, une langue Mandé Centrale, dans les termes des extensions métaphoriques et de la motivation iconique. Cela permet d'élargir la base empirique de la typologie des postpositions d'identification dans les langues Mandé.

В СТАТЬЕ ИССЛЕДУЮТСЯ МОДЕЛИ ПОЛИСЕМИИ ДВУХ ПОСЛЕЛОГОВ В ДЖЕЛИ (ЦЕНТРАЛЬНЫЕ МАНДЕ), МАРКИРУЮЩИХ ПРИНАДЛЕЖНОСТЬ К КЛАССУ И ПРИПИСЫВАЮЩИХ СВОЙСТВА, В ТЕРМИНАХ МЕТАФОРИЧЕСКИХ РАСШИРЕНИЙ И ИКОНИЧЕСКОЙ МОТИВАЦИИ. ТАКИМ ОБРАЗОМ, СТАТЬЯ НАПРАВЛЕНА НА РАСШИРЕНИЕ ЭМПИРИЧЕСКОЙ БАЗЫ ДЛЯ ТИПОЛОГИИ ПОСЛЕЛОГОВ «ИДЕНТИФИКАЦИИ» В ЯЗЫКАХ МАНДЕ.

\section{INDEX}

Subjects: langues mandé centrales, jeli

Keywords: Postpositions, Identificational Clauses, Jeli, Central Mande

motsclesru ПОСЛЕЛОГИ, ПОЛИСЕМИЯ, КЛАУЗЫ ИДЕНТИФИКАЦИИ, ДЖЕЛИ, ЦЕНТРАЛЬНЫЕ

МАНДЕ

Mots-clés: postpositions, polysémie, propositions d'identification 
AUTHOR

HOLGER TRÖBS

University of Mainz

troebs@uni-mainz.de 